\title{
Global distribution of material stocks: iron, copper and nickel
}

\author{
Kenichi Nakajima ${ }^{1,}$, Ichiro Daigo ${ }^{2}$, Keisuke Nansai ${ }^{1}$, Kazuyo Matsubae ${ }^{3}$, Wataru Takayanagi ${ }^{1}$, Makoto Tomita ${ }^{4}$, \\ and Yasunari Matsuno ${ }^{5}$ \\ ${ }^{1}$ Center for Material Cycles and Waste Management Research, National Institute for Environmental Studies, 16-2 Onogawa, \\ Tsukuba, Ibaraki 305-8506, Japan \\ 2 Department of Materials Engineering, Graduate School of Engineering, The University of Tokyo, 7-3-1 Hongo, Bunkyo-ku, \\ Tokyo 113-8656, Japan \\ ${ }^{3}$ Department of Environmental Studies for Advanced Society, Graduate School of Environmental Studies, Tohoku University, \\ Miyagi 980-0845, Japan \\ ${ }^{4}$ Department of Arts, School of Humanities and Culture, Tokai University, 4-1-1 Kitakaname, Hiratsuka, Kanagawa 259-1292, \\ Japan \\ ${ }^{5}$ Department of Urban Environment Systems, Chiba University, 1-33, Yayoicho, Inage Ward, Chiba-shi, Chiba 263-8522 Japan
}

Received: 28 June 2017 / Accepted: 14 December 2017

\begin{abstract}
Economic growth has caused a rapid rise in the use of metals and minerals. In addition, the world's population is projected to rapidly increase, with increases concentrated in Asia and Africa. Asia has become the largest global user of natural resources, and established systems of production and consumption are tailored to the current high levels of natural resource use and the associated emissions. Closing the material cycle loop is a principal strategy to reduce natural resource consumption and associated emissions. Material flow analysis (MFA), widely used to assess the flow and stocks of materials within a system defined in time and space, is regarded as a core tool to assess the sustainability of material use. The objective of this study was to estimate material stocks of iron, copper, and nickel, for which the global demand has risen rapidly in recent years. Specifically, the goal was to examine transitions of the material stock of each substance from 1995 to 2010 . The worldwide material stocks of iron, copper, and nickel drastically increased during this period, which coincided with an increase in demand for materials in Asia. The material stock of each substance in Asia increased almost threefold from 1995 to 2010. The material stock of iron, copper, and nickel in Asia accounted for 30\%, 26\%, and $20 \%$ of the world total in 1995 , respectively, but these percentages increased to $42 \%, 37 \%$, and $32 \%$ in 2010 , respectively. There was also a drastic increase in the per-capita material stock of iron, copper, and nickel in Asia during the same period, but the per-capita material stock of each of these substances in Asia was not yet reached that of North America and Western Europe. The material stocks in Africa increased in line with the population growth in Africa from 1995 to 2010, so the per-capita material stock of each substance in Africa stayed about the same. The per-capita material stocks in Africa are also small compared with developed countries and regions. This situation shows the potential for a greatly increased demand as a result of expansions in production through accelerated industrialization as well as the increased demand for resources accompanying population and economic growth in Asia and Africa.
\end{abstract}

Keywords: material flow analysis (MFA) / supply chain / time series analysis / Asia / Africa / mineral resource

Résumé. Répartition mondiale des stocks de matières : fer, cuivre et nickel. La croissance économique a entraîné une augmentation rapide de l'utilisation des métaux et des minéraux. En outre, on prévoit une rapide augmentation de la population mondiale, l'augmentation étant concentrée en Asie et en Afrique. L'Asie est devenue le plus grand utilisateur mondial de ressources naturelles, et les systèmes établis de production et de consommation sont adaptés aux niveaux élevés actuels d'utilisation des ressources naturelles et aux émissions connexes. Fermer la boucle de cycle des matières est une stratégie principale pour réduire la consommation de ressources naturelles et les émissions connexes. Les comptes de flux de matières (CFM), largement utilisés pour

\footnotetext{
* e-mail: nakajima.kenichi@nies.go.jp
} which permits unrestricted use, distribution, and reproduction in any medium, provided the original work is properly cited. 
évaluer le flux et les stocks de matières dans un système défini dans le temps et dans l'espace, sont considérés comme un outil de base pour évaluer la durabilité de l'utilisation des matières. L'objectif de cette étude était d'évaluer les stocks de fer, de cuivre et de nickel, pour lesquels la demande mondiale a augmenté rapidement ces dernières années. Plus précisément, l'objectif était d'examiner les transitions du stock de matières de chaque substance entre 1995 et 2010. Les stocks mondiaux de matières de fer, de cuivre et de nickel ont radicalement augmenté au cours de cette période, ce qui a coïncidé avec une augmentation de la demande de matières en Asie. Le stock de matières de chaque substance en Asie a presque triplé de 1995 à 2010. Le stock de matières de fer, de cuivre et de nickel en Asie représentait respectivement 30\%, $26 \%$ et $20 \%$ du total mondial en 1995, mais ces pourcentages ont augmenté à $42 \%, 37 \%$ et $32 \%$ en 2010, respectivement. Au cours de la même période, le stock de fer, de cuivre et de nickel par habitant a considérablement augmenté en Asie, mais le stock de matières par habitant de chacune de ces substances en Asie n'a pas encore atteint celui de l'Amérique du Nord et de l'Europe de l'Ouest. Les stocks de matières en Afrique ont augmenté parallèlement à la croissance de la population en Afrique de 1995 à 2010, de sorte que le stock de matières par habitant de chaque substance en Afrique est resté à peu près le même. Les stocks de matières par habitant en Afrique sont également faibles par rapport aux pays et régions développés. Cette situation montre le potentiel d'une demande fortement accrue en raison des expansions de la production par une industrialisation accélérée ainsi que de la demande accrue de ressources accompagnant la croissance démographique et économique en Asie et en Afrique.

Mots clés: comptes de flux de matières (MFA) / chaîne d'approvisionnement / analyse de séries chronologiques / Asie / Afrique / ressources minérales

\section{Introduction}

Economic growth has accelerated the use of natural resources [1,2], which has potential environmental impacts at local and global scales. The United Nations projected that the world's population will reach 9.7 billion by 2050 , with nearly $90 \%$ of the increase concentrated in Asia and Africa [3]. The Asia-Pacific region has become the largest global user of natural resources, and established systems of production and consumption are tailored to the current high levels of natural resource use with their associated emissions. In 2010, the region had a population of 3.6 billion, or $55 \%$ of the global population, and used 36 billion tonnes $(53 \%)$ of global materials [4].

Closing the loop of material cycles is a principal strategy to reduce natural resource consumption and the associated environmental impacts. Policymakers have recognized the importance of circular economy strategies [5], with closed material cycles and the economic stimulation accompanying resource renewal activities attracting attention. Material flow analysis (MFA) is widely used to assess the flows and stocks of materials within systems defined in time and space. It is considered a core tool to assess the sustainability of material use (e.g., Reck and Graedel 2012 [6]; Reck et al. 2008 [7]; Pauliuk et al. 2013 [8]; Nansai et al. 2014 [9]; Wiedmann et al. 2013 [10]; Nakajima et al. 2014, $2017[11,12])$. However, the absence of national statistics constrains the detection of material flows and stocks, making it extremely difficult to understand the distribution of material consumption around the world and clarify the drivers of accelerated material consumption.

The objective of this study was to estimate material stocks of iron, copper, and nickel, the global demand for which has risen rapidly in recent years, by using the global MFA approach established by Nansai et al. [9]. The global extraction of metal ores grew by more than $250 \%$ between 1970 and 2010, and the extraction of iron ore and copper ore account for more than half of the global extraction of metal ores [2]. Moreover, global nickel production has shown nearly exponential growth since 1950 [13]. Materials refined from these ores play a crucial role in modern society, with uses in numerous types of infrastructure and technology. This study therefore clarified global transitions in the material stock of each of these substances from 1995 to 2010.

\section{Methods and data}

Nansai et al. [9] established an approach to create a complete global MFA system boundary, which Nakajima et al. $[11,12]$ used to estimate the flow of iron and nickel associated with global trade in 2005 . We recompiled the dataset and estimated the material stock $(S)$ of substance $i$ in country $p$ at the end of year $t$ as follows:

$$
S_{p, t}^{(i)}=S_{p, t-1}^{(i)}+\Delta S_{p, t}^{(i)}
$$

where $\Delta S_{p, t}^{(i)}$ shows the net addition to the stock of substance $i$ in country $p$ in year $t$. The net addition was calculated by multiplying the apparent consumption of substance $i$ in country $p\left(C_{p, t}^{(i)}\right)$ by the accumulated ratio of substance $i$ in country $p\left(\alpha_{p, t}^{(i)}\right)$; that is, $\Delta S_{p, t}^{(i)}=C_{p, t}^{(i)} \times \alpha_{p, t}^{(i)}$. For this study, we calculated $C_{p, t}^{(i)}$ as follows:

$$
C_{p, t}^{(i)}=M_{p, t}^{(\mathrm{ore}, i)}+M_{p, t}^{(2 n d, i)}+\sum_{k} \sum_{q}\left(f_{q p}^{(k, i)}-f_{p q}^{(k, i)}\right)
$$

where $M_{p, t}^{(\text {ore }, i)}$ is the amount of substance $i$ embedded in mine production in country $p, M_{p}^{(2 n d, i)}$ is the amount of substance $i$ embedded in secondary resources recovered from urban mines in country $p, f_{q p}^{(k, i)}$ is the amount of substance $i$ 


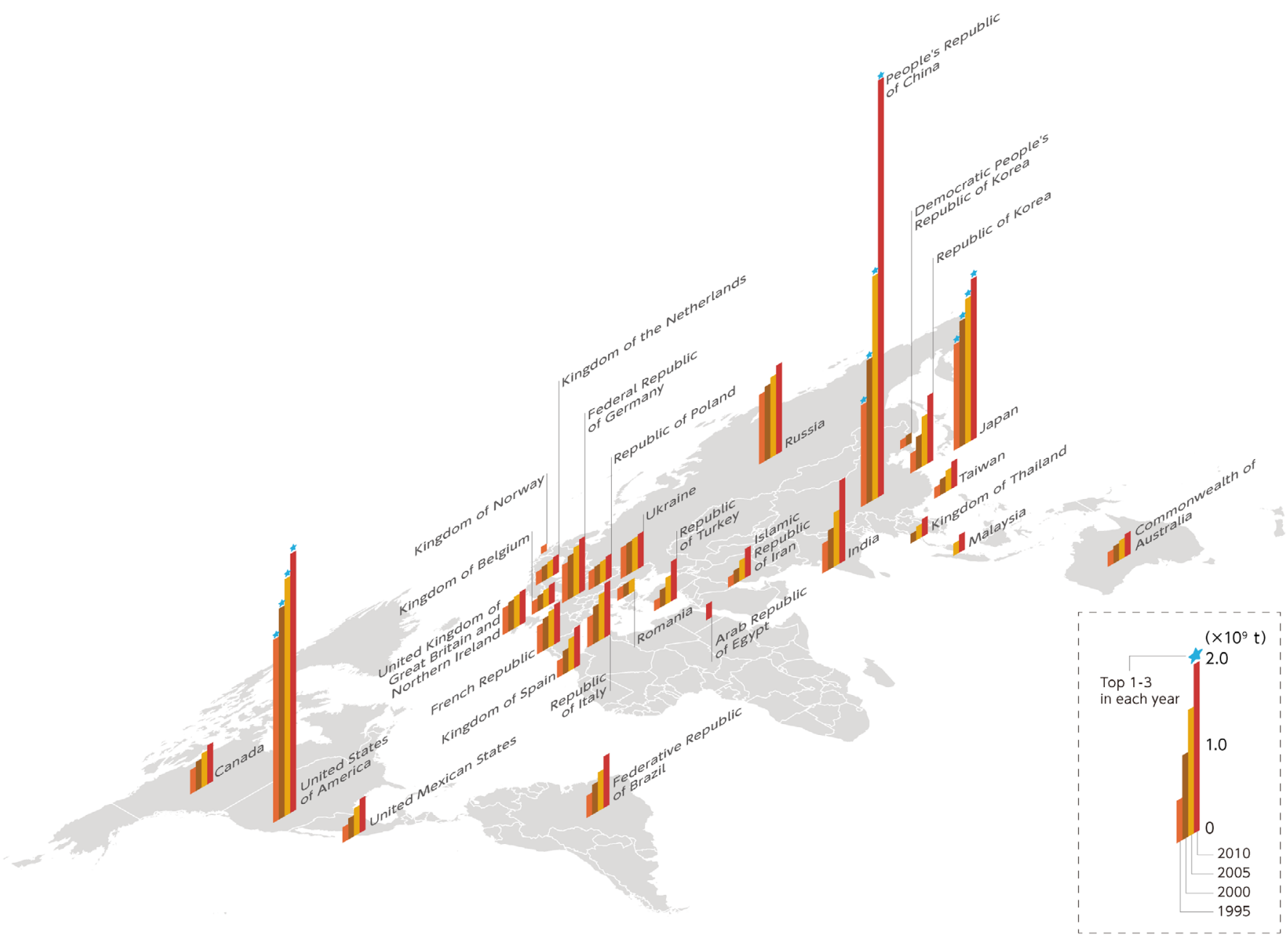

Fig. 1. Distribution of the 25 countries and regions with the largest material stock of iron in 1995, 2000, 2005, and 2010 .

Fig 1. Répartition des 25 pays et régions possédant le stock de fer le plus important en 1995, 2000, 2005 et 2010.

embedded in imports of commodity $k$ from country $q$ to $p$, and $f_{p q}^{(k, i)}$ is amount of substance $i$ embedded in exports of commodity $k$ from country $p$ to $q$. Because of data limitations in trade statistics (Base pour l'Analyze du Commerce International (BACI) [14]; UN Comtrade database) for the calculation of $C_{p, t}^{(i)}$, we calculated $S_{p, 1994}^{(i)}$ from the World Bureau of Metal Statistics (WBMS) [15].

To ensure a global system boundary, we considered 231 countries and regions around the world for $p$ and $q$. To define commodity $k$, we selected all commodities assumed to contain the element among the approximately $6000 \mathrm{com}-$ modities defined by the Harmonized Commodity Description and Coding System (HS) code with 6-digit classification numbers and aggregated the selected ones into $543 \mathrm{com}-$ modity groups (4-digit: 196 commodities; 6-digit: 347 commodities) for iron, 288 commodity groups (4-digit: 196 commodities; 6-digit: 92 commodities) for copper, and 303 commodity groups (4-digit: 205 commodities; 6-digit: 98 commodities) for nickel. We extracted the trade volume for each commodity group in monetary or physical units for 231 countries and regions, using BACI [14]. The amount of substance $i$ embedded in mine production originated from USGS mineral yearbooks (e.g., iron: Tuck 2015 [16]; copper: Brininstool 2015 [17]; nickel: Kuck 2012 [18]), and the amount of substance $i$ embedded in secondary production was estimated from statistics (e.g., iron: World Steel Association 2015 [19]; copper, Brininstool 2015 [17]; nickel, WBMS [15] and Daigo et al. 2010 [20]). We also obtained $\alpha_{p . t}^{(i)}$ from previous MFA studies (iron: Wang et al. 2007 [21]; copper: Graedel et al. 2004 [22]; nickel: Reck et al. 2008 [7]), but the accumulated ratio $\left(\alpha_{p, t}^{(i)}\right)$ was assumed to be constant regardless of the year because of data limitations.

\section{Results}

The 25 countries and regions identified as having the largest material stock of iron are shown in Figure 1. The 


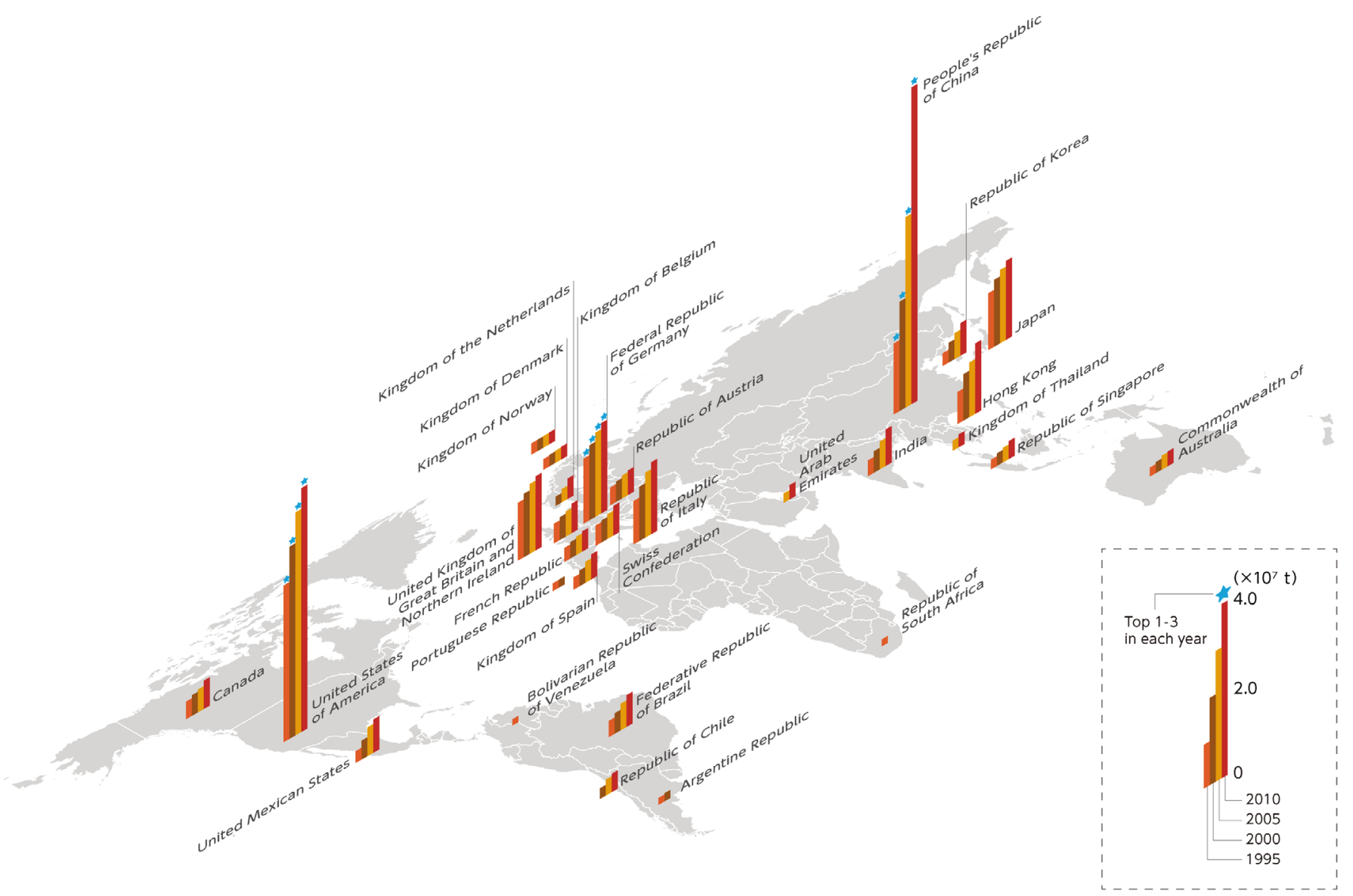

Fig. 2. Distribution of the 25 countries and regions with the largest material stock of copper in 1995, 2000, 2005, and 2010 .

Fig 2. Répartition des 25 pays et régions possédant le stock de cuivre le plus important en 1995, 2000, 2005 et 2010.

total material stock of iron doubled from 1995 to 2010 and was estimated at $24 \times 10^{9} \mathrm{t}-\mathrm{Fe}$ in 2010 . The three countries or regions with the largest material stock accounted for $41 \%$ of the world total in 2010 (PR China: $20 \%$; USA: $13 \%$; and Japan: $7.9 \%$ ), the top 10 accounted for $63 \%$, and the top 25 accounted for $83 \%$. The material stock of iron in Asia and Africa was $11 \times 10^{9} \mathrm{t}-\mathrm{Fe}$ (Asia: $10 \times 10^{9} \mathrm{t}-\mathrm{Fe}$; Africa: $0.81 \times 10^{9} \mathrm{t}-\mathrm{Fe}$ ) in 2010 , which accounted for $46 \%$ (Asia: $42 \%$; Africa: $3 \%$ ) of the world total.

The top 25 countries and regions identified as having the largest material stock of copper are shown in Figure 2. The total material stock of copper was estimated at $37 \times 10^{7} \mathrm{t}-\mathrm{Cu}$ in 2010, which increased by a factor of 1.9 from 1995 to 2010. The three countries with the largest material stock accounted for $40 \%$ of the world total in 2010 (PR China: 19\%; USA: 15\%; and Germany: 5.5\%), the top 10 accounted for $64 \%$, and the top 25 accounted for $83 \%$. The material stock of copper in Asia and Africa was $15 \times 10^{7} \mathrm{t}-\mathrm{Cu}$ (Asia: $14 \times 10^{7} \mathrm{t}-\mathrm{Cu}$, Africa: $1.2 \times 10^{7} \mathrm{t}$ $\mathrm{Cu}$ ) in 2010, or $40 \%$ (Asia: 37\%; Africa: $3 \%$ ) of the world total.

The top 25 countries and regions identified as having the largest material stock of nickel are shown in Figure 3.
The total material stock of nickel was estimated at $29 \times 10^{6} \mathrm{t}-\mathrm{Ni}$ in 2010 , which increased by a factor of 2.2 from 1995 to 2010. The three countries and regions with the largest material stock accounted for $38 \%$ of the world total in 2010 (PR China: 18\%; USA: 11\%; and Japan: 8.1\%), the top 10 accounted for $63 \%$, and the top 25 accounted for 86\%. The material stock of nickel in Asia and Africa was $9.9 \times 10^{6} \mathrm{t}-\mathrm{Ni}$ (Asia: $9.3 \times 10^{6} \mathrm{t}-\mathrm{Ni}$; Africa: $0.64 \times 10^{6} \mathrm{t}-\mathrm{Ni}$ ) in 2010 , which was $34 \%$ (Asia: $32 \%$; Africa: $2 \%$ ) of the world total.

\section{Discussion}

The worldwide material stock of iron, copper, and nickel drastically increased from 1995 to 2010, coinciding with increases in demand for materials in PR China and other Asian countries (Fig. 4). The material stock of each substance in Asia increased almost threefold from 1995 to 2010. The material stock of iron, copper, and nickel in Asia accounted for $30 \%, 26 \%$, and $20 \%$ of the global total in 1995, respectively, and those percentages reached $42 \%$, 


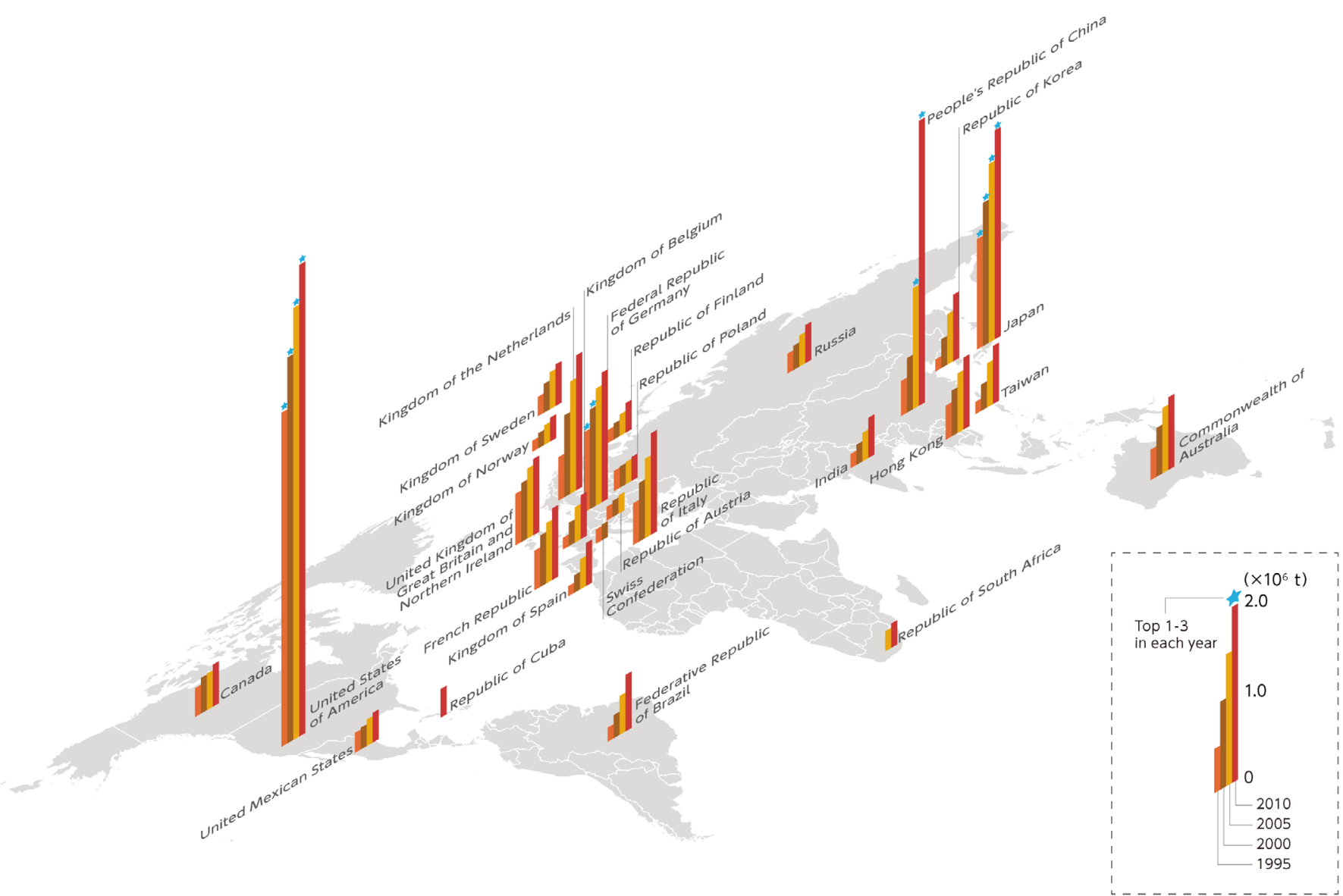

Fig. 3. Distribution of the 25 countries and regions with the largest material stock of nickel in 1995, 2000, 2005, and 2010 .

Fig 3. Répartition des 25 pays et régions possédant le stock de nickel le plus important en 1995, 2000,2005 et 2010.

$37 \%$, and $32 \%$ in 2010 . These results also reveal a dramatic threefold increase in the per-capita material stock of iron, copper, and nickel in Asia from 1995 to 2010. In particular, economic activities in PR China accelerated the rapid rise in material stocks of these substances in Asia. Material stocks in Africa increased in line with the population growth in Africa from 1995 to 2010, so the per-capita material stock of each substance in Africa stayed about the same (Fig. 5).

The world population is projected to increase, with much of that growth concentrated in Asia and Africa. Asia has already become the largest world user of iron, copper, and nickel, but the per-capita material stock of each of these substances in Asia has not yet reached that of North America and Western Europe. The per-capita material stocks in Africa are also small compared with developed countries and regions. This situation shows the potential for a greatly increased demand as a result of expansions in production through accelerated industrialization as well as the increased demand for resources accompanying population and economic growth in Asia and Africa. From the perspective of natural resource conservation, emerging countries in Asia and Africa should introduce and strengthen their recycling systems of each substance to close the material cycle loop.

Acknowledgements. This research was partially supported by the Japan Society for the Promotion of Science (KAKENHI 26281059) and the Environment Research \& Technology Development Fund (1-1402, 1-1601) of the Japanese Ministry of Environment. 


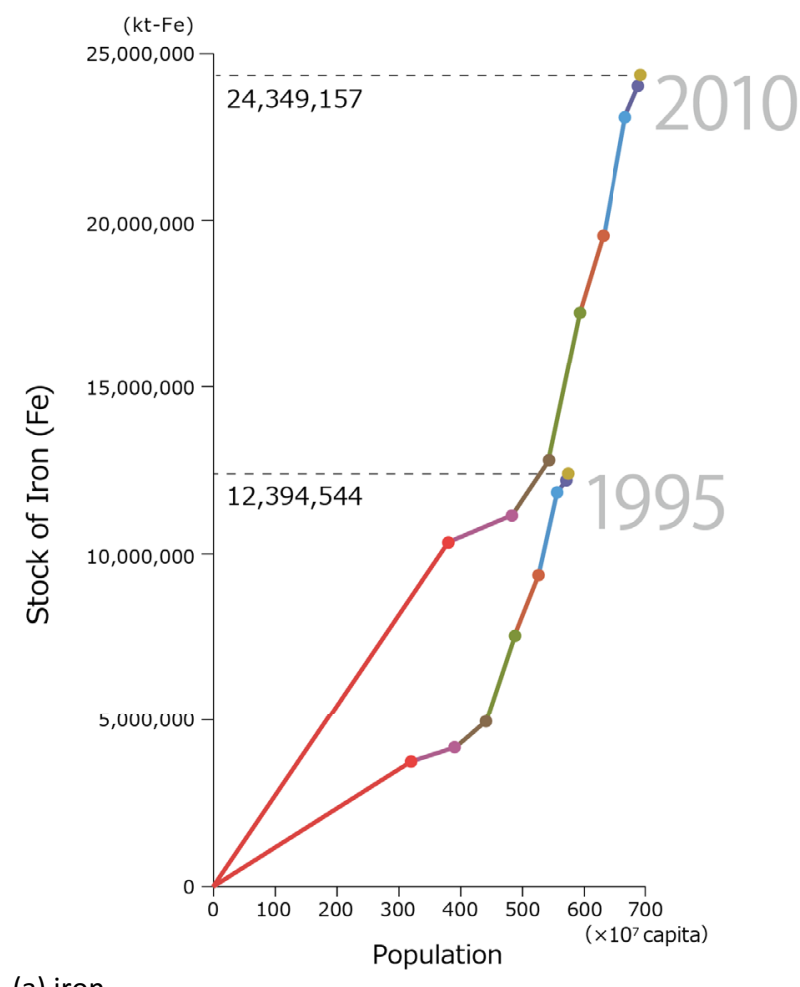

(a) iron

\begin{tabular}{|c|c|c|}
\hline Asia & Africa & Latin America \\
\hline Western Europe & Central-Eastern Europe and Russia & North America \\
\hline Middle East & Oceania & \\
\hline
\end{tabular}

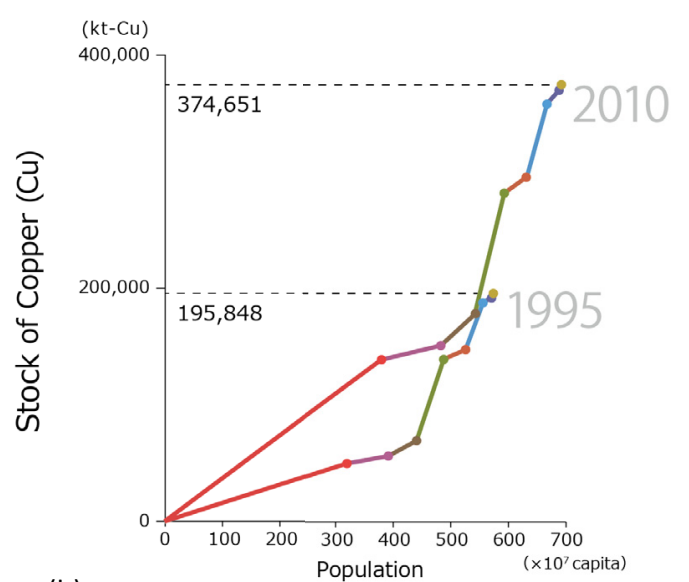

(b) copper

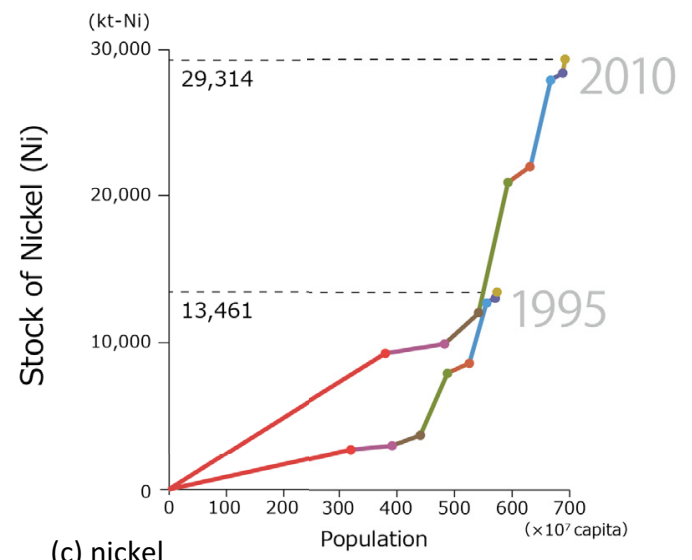

Fig. 4. Distribution of population and material stocks in 1995 and 2010: (a) iron, (b) copper, and (c) nickel.

Fig 4. Répartition des stocks de population et de matières en 1995 et 2010: (a) fer (b) cuivre et (c) nickel.

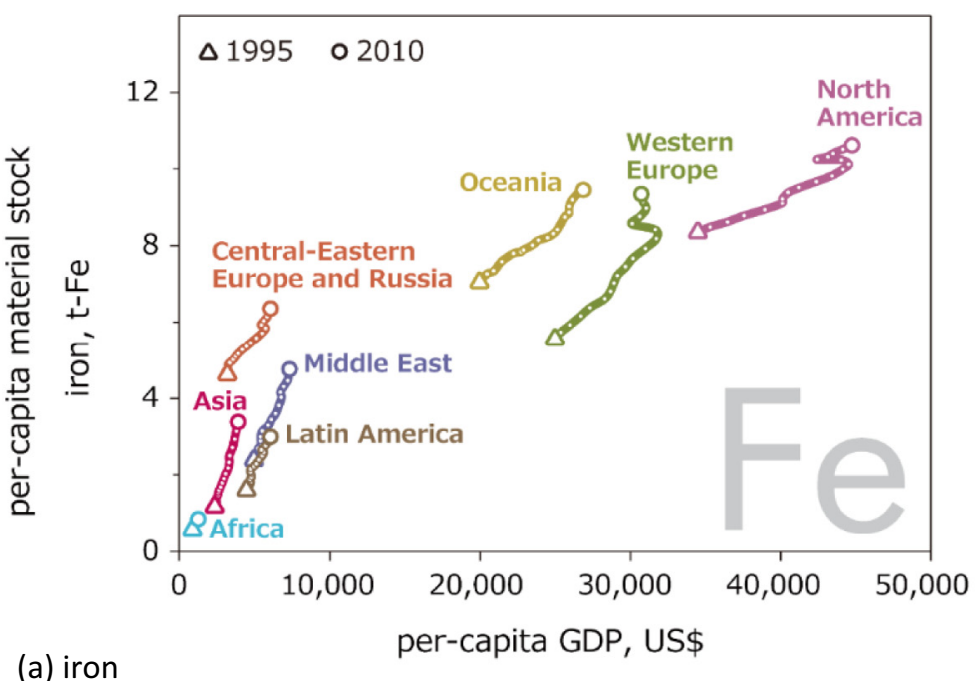

(a) iron

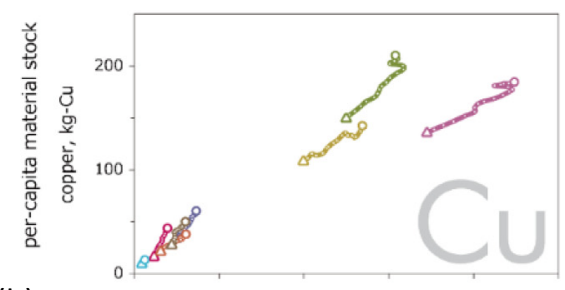

(b) copper

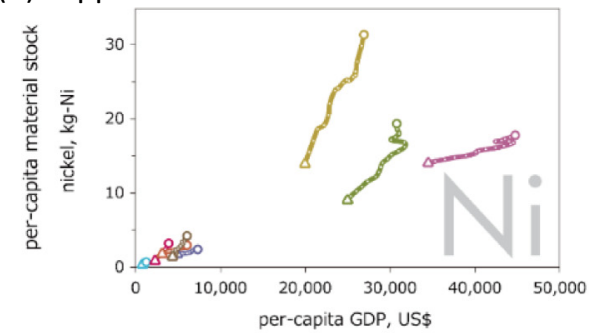

(c) nickel

Fig. 5. Recent trend of material stocks from 1995 to 2010: (a) iron, (b) copper, and (c) nickel.

Fig 5. Tendance récente des stocks de matières de 1995 à 2010: (a) fer (b) cuivre et (c) nickel. 


\section{References}

1. D.P. Van Vuuren, B.J. Strengers, H.J.M De Vries, Longterm perspectives on world metal use-a system-dynamics model, Resour. Policy 25, 239 (1999)

2. United Nations Environmental Programme, International Resource Panel (UNEP IRP), Global material flows and resource productivity, 2016, http://unep.org/documents/ irp/16-00169 LW GlobalMaterialFlowsUNEReport FI NAL_160701.pdf (accessed July 25, 2016)

3. United Nations (UN), World Population Prospects: Key findings \& advance table, 2015, version. 2015, https://esa.un. org/Unpd/wpp/Publications/Files/Key_Fin dings_WPP_2015.pdf (accessed March 20, 2017)

4. United Nations Environmental Programme (UNEP), Indicators for a Resource Efficient and Green Asia and the Pacific, 2015, http://apps.unep.org/redirect.php?file=/pub lications/pmtdocuments/-Indicators for a resource effi cient and green Asia and the Pacific-2015Indicator-

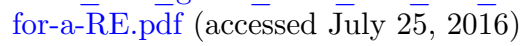

5. M. Geissdoerfer, P. Savaget, N.M.P. Bocken, E.J. Hultink, The Circular Economy-A new sustainability paradigm? J. Clean. Prod. 143, 757 (2017)

6. B.K. Reck, T.E. Graedel, Challenges in metal recycling, Science 337, 690 (2012)

7. B.K. Reck, D.B. Müller, K. Rostkowski, T.E. Graedel, Anthropogenic nickel cycle: Insight to use, trade, and recycling, Environ. Sci. Technol. 42, 3394 (2008)

8. S. Pauliuk, T. Wang, D.B. Müller, Steel all over the world: Estimating in-use stocks of iron for 200 countries, Resour. Conserv. Recycl. 71, 22 (2013)

9. K. Nansai, K. Nakajima, S. Kagawa, Y. Kondo, S. Suh, Y. Shigetomi, Y. Oshita, Global flows of critical metals necessary for low-carbon technologies: the case of neodymium, cobalt, and platinum, Environ. Sci. Technol. 48, 1391 (2014)

10. T.O. Wiedmann, H. Schandl, M. Lenzen, D. Moranc, S. Suh, J. West, K. Kanemoto, The material footprint of nations, PNAS 112, 6271 (2013)

11. K. Nakajima, K. Nansai, K. Matsubae, T. Nagasaka, Material flow of iron in global supply chain, ISIJ Int. 54, 2657 (2014)
12. K. Nakajima, K. Nansai, K. Matsubae, M. Tomita, W. Takayanagi, T. Nagasaka, Global land-use change hidden behind nickel consumption, Sci. Total Environ. 586, 730 (2017)

13. G.M. Mudd, Global trends and environmental issues in nickel mining: Sulfides versus laterites, Ore Geol. Rev. 38, 9 (2010)

14. CEPII, BACI (Base pour l'Analyse du Commerce International): A CEPII World Database of International Trade at the Product Level, 2011.

15. World Bureau of Metal Statistics, Long Term Production/ Consumption Series 1950-2014, 2015

16. C.A. Tuck, Iron ore, USGS 2013 Minerals Yearbook, United States Geological Survey (USGS), 2015, http://minerals. usgs.gov/minerals/pubs/commodity/iron_ore/myb1-2013feore.pdf (accessed July 25, 2016)

17. M. Brininstool, Copper, USGS 2013 Minerals Yearbook, United States Geological Survey (USGS), 2015, http:// minerals.usgs.gov/minerals/pubs/commodity/copper/ myb1-2013-coppe.pdf (accessed July 25, 2016)

18. P.H. Kuck, Nickel, USGS 2012 Minerals Yearbook, United States Geological Survey (USGS), 2015, http://minerals. usgs.gov/minerals/pubs/commodity/nickel/myb1-2012nicke.pdf (accessed July 25, 2016)

19. World steel Association, Steel Statistical Yearbook, 2015, http://www.worldsteel.org/dms/internetDocumentList/ bookshop/2015/Steel-Statistical-Yearbook-2015/docu ment/Steel\%20Statistical\%20Yearbook\%202015.pdf (accessed July 25, 2016)

20. I. Daigo, Y. Matsuno, Y. Adachi, Substance flow analysis of chromium and nickel in the material flow of stainless steel in Japan, Resour. Conserv. Recycl. 54, 851 (2010)

21. T. Wang, D.B. Müller, T.E. Graedel, Forgoing the anthropogenic iron cycle, Environ. Sci. Technol. 41, 5120 (2007)

22. T.E. Graedel, D. Van Beers, M. Bertram, K. Fuse, R.B. Gordon, A. Gritsinin, A. Kapur, R.J. Klee, R.J. Lifset, L. Memon, H. Rechberger, S. Spatari, D. Vexler, Multilevel cycle of anthropogenic copper, Environ. Sci. Technol. 38, 1242 (2004)

Cite this article as: Kenichi Nakajima, Ichiro Daigo, Keisuke Nansai, Kazuyo Matsubae, Wataru Takayanagi, Makoto Tomita, Yasunari Matsuno, Global distribution of material stocks: iron, copper and nickel, Matériaux \& Techniques 105, 511 (2017) 